\title{
The Influence of Transformational Leadership and School Environment on Academic Achievement of PAUD Teachers at West Pontianak District
}

\author{
Nazayanti $^{1)}$, Wahyudi $^{2)}$, M Chiar ${ }^{3)}$ \\ ${ }^{1)}$ Universitas Tanjungpura, Pontianak, Indonesia \\ E-mail: ismi_3yani@yahoo.co.id \\ ${ }^{2)}$ Universitas Tanjungpura, Pontianak, Indonesia \\ E-mail:wyudi_fkip@yahoo.com \\ ${ }^{3)}$ Universitas Tanjungpura, Pontianak, Indonesia \\ E-mail: chiarfkip@gmail.com
}

\begin{abstract}
In general, this research departs from the researchers' thinking that with the better and higher Transformational leadership and school environment, the better and higher the Motivation for Achievement of teachers, especially in PAUD District of West Pontianak. The method used in this study is a type of causal study with a quantitative approach. The instrument used in this study is a questionnaire. The population in this study were Paud educators in West Pontianak Subdistrict with a total of 72 teachers from 26 Paud institutions in West Pontianak Subdistrict. The instrument is divided into three variables: Transformational Leadership (X1), School Environment (X2), and Teacher Achievement Motivation (Y). Based on the analysis, the following results were obtained: first; the significance value of the Transformational Leadership variable (X1) is 0,000 or less than 0.05 so Ha is accepted and Ho Denied. It means that there is a significant influence of Transformational leadership on the achievement motivation of PAUD teachers in West Pontianak Subdistrict, with r X1y 0.66 and r table 0.229 Second; the significance value on the School Environment variable (X2) is 0.00 or less than 0.05 so that Ha is Accepted and Ho is denied. It means that there is a significant influence on the School Environment on the achievement motivation of PAUD teachers in West Pontianak Subdistrict, with $\mathrm{rX} 2 \mathrm{y} 0.685$ with $\mathrm{r}$ table 0.229 . And third; the value of the significance of Transformational leadership and school environment together is 0.00 or less than 0.05. Thus Ha is accepted, and Ho is rejected. It means that there is a significant influence of Transformational leadership and school environment together on teacher achievement motivation in the West Pontianak sub-district, with an $\mathrm{r}$ count of 47.868 and Ftable 3.13, at a significance level of 0.05. On the basis of the results of the study, it is expected that PAUD leaders or managers in West Pontianak Subdistrict should apply Transformational leadership well, it is hoped that the motivation of teachers to develop their existing potential will increase teachers should always spur themselves and continue to improve, develop potential and his achievements to improve the quality of education.
\end{abstract}

Keywords: Transformational Leadership; School Environment; Teacher Achievement Motivation

\section{INTRODUCTION}

Achievement motivation is an impulse or strength and persistence of someone to produce something that is best for themselves and the institution. Achievement motivation is a must that an educator must have to encourage to achieve achievement to know the extent to which his competence can be implemented in individual success and school. According to McClelland (Carlon, 1986) a person has the motivation to work because of the need for achievement, then added by Robert White (Morgan et al. 1986: Worell \& Stilwell, 1981) that every human being has a desire to demonstrate competence by conquering his environment, but for realizing achievement motivation must certainly be influenced by leadership, and those who can realize these expectations are Transformational leadership. 
Transformational leadership is leadership that strives to make changes by giving trust and confidence to its subordinates to achieve its capabilities, and have a better performance in developing its subordinates. The most extensive research on Transformational leadership is carried out by Leithwood and colleagues (1994: Leithwood, Jantzi, and Steinbach, 1998) based on the ideas of Burns and Bass, Leithwood (1994) uses the concept of Transformational leadership to formulate a model in building school vision, establishing school goals, provide intellectual stimulation and offer individual support, exemplify best practices for decision making.

A leader is someone who has resources that have maximum work performance towards the success of an institution in achieving its goals. By being led by a leader who has the appropriate performance, will affect other human resources under his leadership. Leadership in an institution plays a role in influencing subordinate achievement motivation. Therefore a leader with competence as a leader must have adequate competence in carrying out his leadership, such as creating a comfortable organizational environment with all aspects of the achievement of mutually agreed goals. As stated by Hadari Nawawi, (2004) leadership is a very important element because the success and motivation of subordinates depend on how a leader influences his subordinates to achieve common goals.

Then James McGregor Burns's (1978) is an influential book writer to write a book on leadership in which Transformational Leadership calls on the moral values of his followers to increase their awareness so that they are motivated to produce achievements for themselves and their organizations. In addition to transformational leadership, one of the factors that influence a teacher's achievement motivation is the school environment. There is a school environment and things that support the creation of a comfortable school environment so that the people in the organizational environment are motivated to achieve.

The school environment is something that can be observed and created both from personal, social and cultural aspects that can lead to leaders and subordinates in achieving success and achievement so that it can influence their subordinates to achieve. George Litwin and Robert Stringer (1968: 1) mention environment is a series of characteristics that can be measured in the work environment, which is based on the collective perception of humans who live and work in the environment and proven to influence their behavior.

In reality the institution of Paud in West Pontianak Subdistrict has not fulfilled the capacity of teachers in accordance with the theory - the theory of, from 24 institutions with 72 teachers, only 3 schools have outstanding teachers even though only at the city level, even though the government is both from the central level to the district level. Seeking to facilitate so that teachers can develop their potential by holding competitions such as the PTK Jamboree, outstanding teacher competitions, Porseni, and other competitions. Researchers assume that one of the reasons why teachers in the Paud institution in West Pontianak Subdistrict do not have high achievement motivation is due to the leadership patterns and school environment in their respective Paud institutions.

Based on the above background, researchers feel it is very necessary to conduct more in-depth research related to the research title, namely: The Influence of Transformational Leadership and School Environment on the Motivation of the Achievement of Teachers of the Paud District of West Pontianak.

\section{RESEARCH METHOD}

\section{Research Design}

The approach in this study uses a quantitative approach with the type of causal study. This study aims to test the validity of the hypothesis relating to the influence of transformational leadership (x1) on the motivation of teacher achievement (y) school environment (x2) on teacher achievement motivation (y) and transformational leadership (x1) and school environment (x2) together- same effect on teacher achievement motivation (y).

Research Subject

The population in this study were Paud educators in West Pontianak Subdistrict with a total of 72 teachers from 26 Paud institutions in West Pontianak Subdistrict.

\section{Research Instruments}

The instrument is carried out in various ways, namely (a) compiling indicators of research variables, (b) compiling instrument lattices, (c) testing instruments, and testing instrument validity and reliability. Questionnaire (questionnaire) based on three variables namely Leadership Transformational, School Environment and Achievement Motivation The teacher used in this research instrument, and the grid containing variables and indicators as the basis for arranging the statement items in the questionnaire that will be filled by the teachers.

The lattice of research questionnaire consists of three variables, as follows:

1. Transformational Leadership Variables (X 1)

2. School Environment Variables.

3. Achievement Motivation Variables

Validity and Reliability Test Techniques

1. Validity Test

Tests to prove valid and whether or not questionnaire items can be done by looking at the Product Moment correlation coefficient. A correlation coefficient is a number that states the 
relationship between question scores with total score (item-total correlation). In determining whether or not an item will be used is tested for correlation coefficient significance at the 0.05 level. It means that the item is considered valid if it has a significant correlation to the total item score. Validity test is done on each question item, and the results can be seen through the results of r-count compared to $r$ table, where r-table can be obtained through $\mathrm{df}$ $($ degree of freedom $)=\mathrm{n}-2$ (significant $5 \%, \mathrm{n}=$ number of samples )

Test the validity by using the product moment correlation coefficient as follows:

$$
\mathrm{r}_{\mathrm{n}}=\frac{n\left(\sum X Y\right)-\left(\sum X \sum Y\right)}{\left.\sqrt{n\left\{\sum X^{2}\right.}-\left(\sum x\right)^{2} \cdot n \sum Y^{2}-\left(\sum Y\right)^{2}\right\}}
$$

$\mathrm{n}=$ number of subjects (Sugiyono, 2012: 255)

To find out the validity of the instrument items, the results of $r$ count based on the formula above consulted with the table of value criticism of the product moment correlation coefficient. The number of individual tests that were the target of the trial was 72 people. The critical value of one-sided tests (one-tailed test) at a significance level of 0.05 . With $\mathrm{N}=72$ obtained degrees of freedom $(\mathrm{dk})=\mathrm{N}-2$ $=72-2=70$. The magnitude of the correlation coefficient on the one-sided test table (one-tailed test) at the level of 0.05 with the degree of freedom 70 obtained some 0.235 If $r$ counts $>r$ table, then the instrument is valid if $r$ count $\langle r$ table of instruments is invalid. Thus the instrument is considered valid if the item whose correlation coefficient is greater or equal to 0.235 of the value of the critique item.

The research instrument in the form of questionnaires was tested on 72 respondents with the intention of knowing the validity and reliability of the instrument.

\section{Test Reliability}

The value of Cronbach Alpha reflects the high and low reliability of the questionnaire. If the Cronbach Alpha value is above 0.600, the variables in the research can be said to be reliable. To find out the reliability of the method by comparing the value of $r$ table with $r$ alpha value, with the provisions if $r$ alpha is greater than $r$ table then the instrument is said to be valid. The alpha coefficient formula is as follows:

Cronbach alpha formula $(\alpha)$ :

$\mathrm{r}_{11}=\frac{k}{k-1} \times \frac{1-\sum s^{2} b}{s^{2} t o t}$

$$
\text { Where: }
$$

$$
\begin{aligned}
\mathrm{r} 11 & =\text { instrument reliability (reliability } \\
& \text { coefficient) } \\
\mathrm{k} & \text { lots of questions } \\
\sum s^{2} b & =\text { number of grain variants } \\
s^{2} \text { tot } & =\text { total variant }
\end{aligned}
$$

Data Collection Procedures and Techniques

Data collection in this study uses two sources, namely the primary source (respondent). While the method or technique of obtaining data is done through questionnaires. Questionnaire or questionnaire is a list of statements that each item has been provided with an answer to fill out the statement, from a questionnaire that has been distributed to the correspondent.

The questionnaire was circulated to teachers who matched the characteristics of the population in West Pontianak Subdistrict by giving a set of statements or questions to respondents. The dissemination and collection of questionnaire instruments to respondents was carried out on March 28, 2018, until April 28, 2018.

Data Analysis Technique

In analyzing the data in this study, multiple regression analysis techniques are used, namely to determine the degree of influence between variables $\mathrm{X} 1$ to $\mathrm{Y}$, variables $\mathrm{X} 2$ to $\mathrm{Y}$, and variables $\mathrm{X} 1$ and variables $\mathrm{X} 2$ to $\mathrm{Y}$. To test hypotheses using regression techniques with the following formula (Sugiyono, 2013: 267).

$$
\mathrm{Y}=\mathrm{a}+\mathrm{b} 1 \mathrm{X} 1+\mathrm{b} 2 \mathrm{X} 2
$$

Where:

$\mathrm{Y}=$ Teacher's achievement motivation

X1 = Transformational Leadership

$\mathrm{X} 2$ = School environment

$\mathrm{a}=$ Constants

$\mathrm{b}=$ regression coefficient

Test statistical requirements through normality test and linearity test. Data normality test is intended to find out whether or not the results of research data are normal. Linearity test is to determine the relationship between two variables whether linear or not significantly. According to Riduwan (2010: 177) research using regression analysis and correlation test, it is necessary to conduct a prerequisite test for normality and linearity.

Based on the above opinion, before analyzing using parametric statistics, the data collected must be tested for analysis requirements by testing normality and linearity.

Data Analysis Requirements Test Techniques

1. Data Normality Test

The normality test is done to find out whether the residual values (differences that exist) studied have a normal or abnormal distribution. Residual values that are normally distributed will form a bellshaped curve.

To test the normality in this study, the Kolmogorov Smirnov Z (KS) test is used with the following hypothesis: If the probability value 0.05 is smaller or equal to the probability value Sig or [0.05 sig), then Ho is accepted, and $\mathrm{Ha}$ is rejected by, in other words, the data is normally distributed. If the probability value 0.05 is greater than the probability value Sig or [0.05> sig], then Ho is rejected, and $\mathrm{Ha}$ is accepted in other words the data is not normally distributed.

2. Research linearity test 
Linearity test aims to determine whether two variables have a linear or not significant relationship. This test is carried out as a prerequisite in correlation analysis or linear regression. Testing on SPSS 23 for windows at a significance level of 0.05 . Two variables are said to have a linear relationship if the significance is less than 0.05 .

\section{Hypothesis Test Technique}

To get results in accordance with the research referred to above, what is needed is a correlation test conducted to determine the relationship between the research variables and at the same time opening the hypothesis. The variables tested in this study were Transformational Leadership, School Environment, and Teacher's Achievement Motivation by using SPSS 23 for Windows and the use of multiple regression formulas.

The analysis technique used in this study is multiple regression of two independent variables. This analysis will be used in testing the effect of variables $\mathrm{X} 1$ and $\mathrm{X} 2$ on $\mathrm{Y}$. This analysis is to determine the effect of Transformational Leadership (X1), and School Environment (X2) together have a significant effect on the Achievement of Teachers' Achievement (Y) in West Pontianak Subdistrict. After the requirements are met, the next step is to do data analysis for submitting hypotheses. Hypothesis testing is a step to prove the requirements stated in the formulation of a hypothesis.

1. First Hypothesis Testing (H1)

To test the hypothesis of this study used multiple linear regression analysis techniques with the following steps:

a. Formulating Hypotheses

Ha: Transformational leadership has a significant effect on the achievement motivation of PAUD teachers in West Pontianak Subdistrict.

Ho: There is no significant influence of Transformational leadership on the achievement motivation of PAUD teachers in West Pontianak Subdistrict.

b. Establish Significance Levels

Significance can be known from multiple linear analysis using SPSS 23 for windows with the regression coefficient output.

2. Testing the Second Hypothesis (H2)

To test the hypothesis of this study used multiple linear regression analysis techniques with the following steps:

a. Determine the hypothesis

Ha: School environment has a significant effect on the achievement motivation of PAUD teachers in West Pontianak Subdistrict.

Ho: There is no significant influence on school environment

Against the achievement motivation of PAUD Teachers in West Pontianak Subdistrict.

b. Establish Significant Levels.
Significance can be known from multiple linear analysis using SPSS 23 for windows with the regression coefficient output.

3. Testing the third hypothesis (H3).

In testing the third hypothesis $(\mathrm{H} 3)$, the researcher uses multiple linear regression analysis techniques with the following steps:

a. Determining Hypothesis.

Ha: Transformational leadership and school environment have a significant effect on the achievement motivation of Paud district teachers in West Pontianak.

Ho: There is no significant influence of Transformational leadership and school environment on the achievement motivation of teachers in the West Pontianak District.

b. Establish Significant Levels.

Significance can be known from multiple linear analysis using SPSS 23 for windows with multiple regression coefficient outputs. From the table, it can be seen that coefficient values are regression of Transformational Leadership and School Environment 0,000. This value is smaller than 0.005 or sig $<\alpha$. It means that the research hypothesis states that "Transformational leadership and school environment have a significant effect on the achievement motivation of PAUD teachers in West Pontianak Sub-district" accepted."

c. Determine the value of Fcount and Ftable

In addition to using probability values or sig values, another method that can be used is to compare the calculated $\mathrm{F}$ value with the $\mathrm{F}$ table. Assessment criteria using this method is, if $\mathrm{F}$ count is greater than $\mathrm{F}$ table, the research hypothesis is accepted, and vice versa. In this study, $\mathrm{F}$ arithmetic has a value of 31.464 while the $\mathrm{F}$ table is 3.990 . It means that $F$ counts> F table, so the research hypothesis is accepted, or rejects Ho.

d. Determining the Value of Determination

This analysis is used to determine the amount or percentage of the contribution of the influence of independent variables in a regression model that simultaneously or jointly influences the dependent variable. So the coefficient shows the extent to which the model formed can explain the actual conditions.

The coefficient can be interpreted as the amount of proportion or percentage of $\mathrm{Y}$ variability (dependent variable) explained by $\mathrm{X}$ (independent variable). Briefly, the coefficient is to measure the effect of the variable $X$ (independent variable) on the variable Y (dependent variable).

\section{A. Result}

\section{RESULT AND DISCUSSION}

Description Data presented from the results of this study is to provide a general description of the distribution of data obtained in the field. This study consisted of two independent variables and one 
dependent variable namely Transformational Leadership (X1), School Environment (X2) and Teacher Achievement Motivation (Y) conducted on 72 Paud teachers in West Pontianak Subdistrict.

1. Transformational Leadership Data (X1)

Transformational Leadership variable data was obtained by distributing questionnaires to 72 teachers with a total of 30 items with alternative answers as many as four answer options, very good, good, not good, and not very good. The results of distributing questionnaires were analyzed using SPSS obtained by distributing empirical scores, i.e., the lowest score 42 and the highest score was 116 with a range of 74 Mean 92.59 with an average score of 6663 and a standard deviation of 19,777 . After we know Range (R) can be used to determine the length of the interval class $(\mathrm{p})$ with many classes (k) as many as 4 answer options by using the Formula: $\mathrm{p}=\mathrm{R} / \mathrm{K}=74 / 4=18.5$ then it can be known to many classes $=4$ and class length $=18.5$ then the frequency distribution of Transformational Leadership variables is:

\section{Table I}

Frequency Distribution of Transformational Leadership Variables

\begin{tabular}{ccccc}
\hline $\begin{array}{c}\text { Class } \\
\text { Number }\end{array}$ & Interval & $\begin{array}{c}\text { Absolute } \\
\text { Frequency }\end{array}$ & $\begin{array}{c}\text { Relative } \\
\text { Frequency (\%) }\end{array}$ & Criteria \\
\hline 1 & $42-59,5$ & 6 & 8,3 & Very Poor \\
\hline 2 & $60,5-78$ & 11 & 15,5 & Poor \\
\hline 3 & $79-96,5$ & 16 & 22,2 & Good \\
\hline 4 & $97,5-116$ & 39 & 59,2 & Very Good \\
\hline Total & & 72 & 100 & \\
\hline
\end{tabular}

From the above data can be seen the highest score of 59.2 with an interval range of $97.5-116$ with very good criteria, while for the lowest score is 8.3 with a range of $42-59.5$, thus it can be concluded that Transformational Leadership has a very good influence.

2. School environment data

School environment variable data was obtained by distributing questionnaires to 72 teachers with a total of 22 statement items with alternative answers as many as four answer options, very conducive, conducive, not conducive, not very conducive. The results of questionnaire distribution were analyzed using SPSS

empirical scores obtained were the lowest score of 48 , and the highest score was 88 with a range of 40 Mean 75.51 with an average score of 5437 and a standard deviation of 12.006. After that we know Range (R) can be used to determine the length of the interval class (p) with many classes (k) as many as 4 answer options using the Formula: $p=R / K=40 / 4=10$ it can be seen many classes $=4$ and class length $=10$ then the variable frequency distribution of the school environment is:

Table II
Variable Frequency Distribution of School Environment

\begin{tabular}{lclll}
\hline Class Number & Interval & $\begin{array}{l}\text { Absolute } \\
\text { Frequency }\end{array}$ & $\begin{array}{l}\text { Relative } \\
\text { Frequency (\%) }\end{array}$ & Criteria \\
\hline 1 & $48-57$ & 9 & 12,5 & $\begin{array}{l}\text { Not Very } \\
\text { Conducive }\end{array}$ \\
\hline 2 & $58-67$ & 10 & 13,9 & Not Conducive \\
\hline 3 & $68-77$ & 11 & 15,3 & Conducive \\
\hline 4 & $78-88$ & 42 & 58,3 & Very Conducive \\
\hline Total & & 72 & 100 & \\
\hline
\end{tabular}

From the above data, it can be seen the highest score of 58.3 with interval range $78-88$ with very conducive criteria while for the lowest score is 12.5 with a range of $48-57$. Thus it can be concluded that the influential school environment is very conducive.

3. Achievement Motivation Variables

Achievement Motivation data was obtained by distributing questionnaires to 72 teachers with the number of statements as many as 24 items statement with the number of alternative answers four answer options, very good, good, not good, not very good. The results of the questionnaire distribution were analyzed using SPSS with the spread of empirical scores, i.e., the lowest score of 61 and the highest score of 93 with the range 32 Mean 78.42 with an average score of 5646 and a standard deviation of 7,691. After that we know Range (R) can be used to determine the length of the interval class (p) with many classes (k) as many as 4 answer options by using the Formula: $\mathrm{p}=\mathrm{R} / \mathrm{K}=32 / 4=8$ it can be seen many classes $=4$ and class length $=8$ then variable frequency distribution Achievement motivation is:

Table III

Frequency Distribution of Achievement Motivation Variables

\begin{tabular}{lclll}
\hline Class Number & Interval & $\begin{array}{l}\text { Absolute } \\
\text { Frequency }\end{array}$ & $\begin{array}{l}\text { Relative } \\
\text { Frequency (\%) }\end{array}$ & Criteria \\
\hline 1 & $48-57$ & 9 & 12,5 & $\begin{array}{l}\text { Not Very } \\
\text { Conducive }\end{array}$ \\
\hline 2 & $58-67$ & 10 & 13,9 & Not Conducive \\
\hline 3 & $68-77$ & 11 & 15,3 & Conducive \\
\hline 4 & $78-88$ & 42 & 58,3 & Very Conducive \\
\hline Total & & 72 & 100 & \\
\hline
\end{tabular}

From the data above can be seen the highest score 3 3, 3 with interval range 85 - 93 with criteria very good, good, not good, very bad while for the lowest score is 8,3 with range 61 68. Thus it can be concluded that Achievement motivation has a very good effect.

1. Test Data Analysis Requirements

a. Data Normality Test

The normality test is done to find out whether the residual values (differences that exist) studied have a normal or abnormal distribution. Residual values that are normally distributed will form a bell-shaped curve.

To test for normality in this study, the Kolmogorov Smirnov Z (K.S) test was used with the following hypothesis: 
Ho is accepted $=$ If the probability value is 0.05 <probability value $\mathrm{Sig}$ or $[0.05 \mathrm{sig}$, meaning that the data is normally distributed.

Ho is rejected $=$ If the probability value is $0.05>$ the probability value is Sig or [0.05> sig], meaning that the data is not normally distributed.

Based on the calculation using SPSS, the probability value $\mathrm{Sig}=0.200$ is obtained so that the probability value is $0.05<$ value of Sig = 0.200 . Thus it can be concluded that $\mathrm{Ho}$ is accepted and, meaning that the data is normally distributed.

\section{b. Linearity Research Test}

Linearity test aims to determine whether two variables have a linear or not significant relationship. This test is carried out as a prerequisite in multiple regression analysis. Testing on SPSS 23 for windows at a significance level of 0.05 . Two variables are said to have linear relationships if the significance value is greater than 0.05 .

Based on SPSS analysis, the results obtained can be expressed in the form of linearity test tables. The linearity test results can be seen in the following table:

$$
\text { Table IV }
$$

Linearity Test Results

\begin{tabular}{lllll}
\hline No & Variabel & F linearity & Sig & Linearity \\
\hline 1 & $\mathrm{X}_{1}$ with $\mathrm{Y}$ & 0,346 & 0,000 & Linear \\
\hline 2 & $\mathrm{X}_{2}$ with $\mathrm{Y}$ & 0,262 & 0,000 & Linear \\
\hline
\end{tabular}

Based on the results of the SPSS test table above, it can be interpreted that:

1) Based on the linearity test results in table 4.4 above, it is known that Flinieriti for the influence of $\mathrm{X} 1$ with $\mathrm{Y}$ is 0.346 with a significance level of 0.000 . Because the Flinierity is positively rated (0.346) and the significance level $(0.000)$ is greater than 0.05 . So the conclusion is that between achievement motivation and transformational leadership is expressed linearly.

2) Furthermore, if viewed from the linearity of motivation with achievement in the school environment, the results of the linearity test in Table 4.4 above note that Flinieriti for the influence of $\mathrm{X} 2$ with $\mathrm{Y}$ is 0.262 with a significance level of 0.000 . Because the Flinierity is positively rated $(0.262)$ and the significance level $(0.000)$ is greater than 0.05 . Then it can be concluded that between the achievement motivation and the school environment is stated to be linear.

2. Hypothesis Testing

After the testing requirements are met, then the next is to do data analysis to test the hypothesis. The analysis technique used in this study is multiple regression of two independent variables. This analysis will be used in testing the effect of variables $\mathrm{X} 1$ and $\mathrm{X} 2$ on $\mathrm{Y}$. This analysis is to determine the effect of Transformational Leadership (X1), and School Environment (X2) together have a significant effect on the Achievement of Teachers' Achievement (Y) in West Pontianak Subdistrict.

a. Effect of Transformational Leadership on Teacher's Achievement Motivation

The first Research Hypothesis (H1):

Ha: Transformational leadership has a significant effect on the achievement motivation of early childhood teachers in West Pontianak Subdistrict.

Ho: There is no significant influence of Transformational leadership on the achievement motivation of PAUD teachers in West Pontianak Subdistrict.

Statistical hypothesis:

Ha: $r X 1 Y \neq 0$

Ho: $r X 1 Y=0$

Criteria:

$\mathrm{Ha}$ is accepted, and $\mathrm{Ho}$ is rejected if the Significance value is smaller than the probability value 0.05 ( $\mathrm{Sig}<0.05$ ), otherwise $\mathrm{Ha}$ is rejected, and Ho has accepted if the Significance value is greater or equal to the probability value 0.05 (Sig> 0.05).

After testing it turned out that $\mathrm{Ha}$ was received in the sense that there was a significant influence on Transformational leadership on the achievement motivation of early childhood teachers in West Pontianak sub-district. It was based on the SPSS calculation. Ha is accepted, and $\mathrm{Ho}$ is rejected. It means that there is a significant influence of Transformational leadership on the achievement motivation of PAUD teachers in West Pontianak Subdistrict. It means that the better the Transformational leadership is applied, the higher the teacher's Achievement Motivation.

b. Effect of School Environment on Teacher's Achievement Motivation

Second research hypothesis $(\mathrm{H} 2)$ :

Ha: School environment has a significant influence on the achievement motivation of PAUD teachers in West Pontianak sub-district.

Ho: There is no significant influence of the school environment on the achievement motivation of early childhood teachers in Pontianak Barat sub-district.

Statistical hypothesis:

Ha: $r X 2 Y \neq 0$

Ho: $r X 2 Y=0$

Criteria:

$\mathrm{Ha}$ is accepted, and Ho is rejected if the value of the Significance value is smaller than the 
probability value 0.05 ( $\mathrm{Sig}<0.05$ ), otherwise $\mathrm{Ha}$ is rejected, and Ho has accepted if the value of the Significance value is greater or equal to the probability value 0.05 ( $\mathrm{Sig}>0.05$ ).

Based on the results of SPSS analysis, the significance value of the School Environment variable (X2) is 0.00 or less than 0.05 so that $\mathrm{Ha}$ is accepted and Ho is rejected. It means that there is a significant influence on the School Environment on the achievement motivation of PAUD teachers in West Pontianak Subdistrict. It means that the better the school environment, the higher the teacher's Achievement Motivation.

c. Effect of Transformational Leadership and School Environment on Teacher's Achievement Motivation

Third Research Test (H3):

Ha: Transformational leadership and school environment have a significant effect on the achievement motivation of Paud district teachers in West Pontianak.

Ho: There is no significant influence of Transformational leadership and school environment on the achievement motivation of teachers in the West Pontianak District.

The statistical hypothesis in this study is as follows:

Ha: $r X 1 X 2$ Y $\neq 0$

Ho: $r X 1 X 2 \mathrm{Y}=0$

Criteria:

Ha is accepted, and Ho is rejected if the value of the Significance value is smaller than the probability value 0.05 ( $\mathrm{Sig}<0.05$ ), otherwise $\mathrm{Ha}$ is rejected, and Ho has accepted if the value of the Significance value is greater or equal to the probability value 0.05 (Sig> 0.05).

Based on the SPSS calculation, the value of the significance of Transformational leadership and school environment is obtained by 0.00 or less than 0.05. Thus $\mathrm{Ha}$ is accepted, and Ho is rejected. It means that there is a significant influence of Transformational leadership and school environment together on the achievement motivation of teachers in the West Pontianak Subdistrict. And it means that the better the Transformational leadership is applied and the better the school environment, the higher the Teacher Achievement Motivation.

Considering the significant influence of Transformational leadership variables and school environment variables together on the achievement motivation variables of PAUD teachers, it is necessary to calculate how much influence these two free variables (Transformational Leadership and School Environment) on the dependent variable (Achievement Motivation) through Determinant analysis. This terminated analysis is used to determine the amount or percentage of the contribution of the influence of independent variables in a regression model that simultaneously or together have a significant influence on the dependent variable. Based on the SPSS calculation, determination coefficient is $0.581 \%$.

B. Discussion

1. The influence of Transformational leadership on teacher achievement motivation.

Transformational leadership is leadership that is related to someone's behavior to influence others so that they have the desire and willingness to develop the potential that exists in the educator or teacher under his leadership. Gary Yukl (2001: 04) explains in the table the definition of Transformational leadership that is about individual behavior that leads to group activities to achieve common goals, and this leadership also leads to structures in the form of the ability to influence others in certain situations so that they are willing to cooperate in achieving the goals has been determined. Gary Yukl (2001: 315) mentions Transformational leadership behaviors of tolerance stronger, more consistent, and effective, with leadership that has guidelines for stating a clear and interesting vision.

Next Gary Yukl (2005: 305) explains Transformational Leadership is behavior that has an ideal influence, individual consideration, inspiration motivation, and intellectual stimulation. Conger (2015: 261) states that Transformational leaders inspire followers to go beyond self-interest and are extraordinary as examples of Transformational leader Conger said Richard Branson of Virgin Group is the right example for a Transformational leader, Transformational leaders are more effective because they are more creative and they always encourage their followers to be more creative.

Based on some opinions that have been stated above, researchers can understand that Transformational leaders can improve teacher achievement motivation. Likewise, in the PAUD area of West Pontianak sub-district, if the managers or leaders in the PAUD area in West Pontianak subdistrict apply a transformational leadership pattern, then the teacher's achievement motivation can be ascertained to increase. It is consistent with the results of this study, namely: the results of the significance value obtained in the Transformational Leadership variable (X1) is 0,000 or less than 0.05 . (can be seen in table 4.5) which proves that there is a significant influence of Transformational leadership on the achievement motivation of PAUD teachers in West Pontianak Subdistrict.

2. Effect of school environment on teacher achievement motivation

School Environment, talking about environment widely is according to Reichers and Schneider, broader describes shared perceptions concerning various things that are around us, and narrowly is the school environment is defined as a shared perception of organizational policies or 
implementation procedures both formally and nonformally. Mcevoy in Miler and Khoza (2008: 158) states the school environment refers to attitudes, beliefs, norms, and values that underlie the practice of learning and operating a school.

Survey results from Linker in Davis and Newstrom (1990: 24) for the organizational environment include factors of leadership, motivation, communication, interaction influence of decision making in setting goals and controls. According to Tagiuri and Litwin in Wirawan (2007: 121) "a relatively enduring quality of the internal environment of an organization that (a) is experienced by its members, (b) influences their behavior, and can be described as in terms of the values of a particular cell of characteristics (or attributes of the organization).

The quality is relatively lasting from the outside environment of an organization that (a). The experience of members (b). The influence of the habits and can be described regarding certain values of the character or attributes of an organization. Tagiuri and Litwin also added that organizational environment is the quality of the internal environment of the organization which is relatively continuously experienced by members of the organization, Carolyn S Andersen in Wirawan (2007: 122) define the school environment as a sense of school as perceived by those who work or who attend classes at school.

Based on some of the opinions stated above, researchers can understand that the school environment can improve teacher achievement motivation. Likewise, in the PAUD area of West Pontianak sub-district, if the school environment in the PAUD neighborhood in West Pontianak district is good, then the teacher's achievement motivation will certainly increase. It is consistent with the results of this study, namely: the results of the significance value obtained in the School Environment variable (X2) is 0,000 or less than 0.05 . (can be seen in table 4.6) Which proves that there is a significant influence of School Environment on the achievement motivation of PAUD teachers in West Pontianak Subdistrict.

3. Effect of Transformational Leadership and School Environment on teacher achievement motivation.

Motivation is interpreted broadly as a driving force that can become active, Mulyasa (2003: 112) states motivation as a driving force or puller that causes behavior towards a particular goal. David C McClelland in Luthans (2006: 24) mentions profiles of people who have high motivation are people like:

1). Taking a risk is moderate because successful people will take a moderate risk, 2). Feedback needs, someone who has achievement motivation likes activities that provide feedback and are valuable about progress towards achieving goals.
3). Satisfied with achievement, achievement motivation assumes that the completion of a task is a pleasant thing and does not expect material appreciation. 4). Having fun with assignments or jobs, people who have achievement motivation tend to work on assignments and finish.

At Atkinson's theory of expectancy-value (1960) suggests that one's achievement motivation is based on two things: the tendency to achieve success and the tendency to avoid failure, agree with Gagne and Baseline (1975: 77) achievement motivation is the way someone tries well for his achievements, then Mc Clelland quoted in B Uno Hamzah (2006: 47) achievement motivation is emphasizing the importance of the need for achievement, because successful people are people who solve everything that is marked by merging, strength and achievement.

From the above quotations, researchers can understand that teacher achievement motivation is influenced by the desire to succeed. The desire for success can arise naturally from the teacher's wishes but can also be caused by external factors such as the pattern of transformational leadership and the school environment.

A transformational PAUD leader will always direct group activities in this case PAUD teachers to move forward and achieve common goals; transformational PAUD leaders will always contribute to the success of the teachers in their institutions. What's more, if the school environment supports, all teachers and students with an atmosphere that prioritizes cooperation, trust, loyalty, openness, commitment, and mutual support to progress and excel, then it can be ascertained will affect increasing teacher's motivational management. It is consistent with the results of this study which can be seen from the significance value of transformational leadership and school environment on achievement motivation of 0.00 or less than 0.05 . Thus it is proved that there is a significant influence of Transformational leadership and school environment together on the teacher achievement motivation of the West Pontianak Subdistrict with the magnitude of influence (Coefficient of Reflected) is $0.581 \%$.

\section{CONCLUSIONS AND SUGGESTIONS}

\section{A. Conclusions}

The results of the study by collecting data, analyzing data and testing hypotheses, can be concluded in general that there is a positive influence between Transformational Leadership and School Environment on the Achievement Motivation of Paud teachers in West Pontianak District, while the conclusions are as follows:

1. Transformational Leadership influences the Motivation of Achievement of Paud teachers in West Pontianak Subdistrict, meaning that the 
better the Transformational leadership is applied, the higher the Teacher Achievement Motivation.

2. The school environment affects the Motivation of the Achievement of Paud teachers in West Pontianak Subdistrict, meaning that by creating a good and high school environment, the motivation for teacher achievement is better and higher.

3. There is a significant influence of Transformational Leadership and school climax together on the Achievement Motivation of the Paud District Teachers in West Pontianak, with the better and higher Transformational leadership and school environment, the better and higher the Teacher Achievement Motivation is.

\section{B. Suggestions}

The results of the study are a description of the results achieved from a situation which occurs in an area where the research is carried out. Therefore the suggestions that can be given are as follows:

1. For the Head of PAUD, he/she should apply the leadership pattern; namely, by applying the Transformational leadership, it is expected that the motivation of the teacher to develop the potential of the teacher will increase so that the teacher will be motivated to work

2. For teachers, it is advisable always to be able to improve and spur their achievement motivation when Transformational leadership and school environment have been created by institutions and leaders where the teacher is serving.

\section{REFERENCES}

Conger. 2015. Charismatic Leadership. Jakarta: Salemba Empat.

Davis, K. \& Newstrom, J.W. 1990. Perilaku dalam Organisasi Jilid 1 (7th ed). Terjemahan A.Dharma. Jakarta: Erlangga.

E, Mulyasa. 2003. Manajemen Berbasis Madrasah, Konsep Strategi dan Implementasi. Bandung: Rosdakarya.

Gary, Yukl. 2001. Kepemimpinan dalam Organisasi. Jakarta: Indeks.

Hamzah, B. U. 2016. Teori Motivasi \& Pengukurannya. Jakarta: PT Bumi Aksara.

Luthans. 2006. Organizational Behavior (10 th edition) Terjemahan, Yuwono,V A, Purwanti, S, Arie P, dan Rosari, W. Yogyakarta.

Nawawi, H. 2004. Manajemen Sumber Daya Manusia Perusahaan. Bandung: Remaja Rosdakarya.

Sugiyono. 2012. Metode Penelitian Kuantitatif Kualitatif dan R\&D. Bandung: Alfabeta.

Wirawan, 2007. Budaya dan Iklim Organisasi. Jakarta: Salemba Empat. 